\title{
Perceptions and practices of mothers and caregivers on common diseases in children under five years of age in a Mayan community in Yucatán, México
}

\section{Percepciones y prácticas de madres y cuidadoras sobre enfermedades comunes en niños menores de cinco años en una comunidad maya de Yucatán, México}

\author{
RODRÍGUEZ-ANGULO, Elsa†, AGUILAR-FRANCO, Laura, OJEDA-RODRÍGUEZ, Ricardo and
} ANDUEZA-PECH, Guadalupe

Centro de Investigaciones Regionales "Dr. Hideyo Noguchi”, Universidad Autónoma de Yucatán, Mexico.

ID $1^{\text {st }}$ Author: Elsa, Rodríguez-Angulo

ID $1^{\text {st }}$ Co-author: Laura, Aguilar-Franco

ID $2^{\text {nd }}$ Co-author: Ricardo, Ojeda-Rodríguez

ID $3^{\text {rd }}$ Co-author: Guadalupe, Andueza-Pech

DOI: $10.35429 / E J R G .2020 .11 .6 .5 .12$

Received July 20, 2020; Accepted December 30, 2020

\begin{abstract}
Community perceptions and practices towards the disease are mainly influenced by traditional medicine. The intercultural perspective in health allows building symmetrical relationships between medical and traditional knowledge. One of the most vulnerable group is under five years age. Exploring the perceptions and practices of mothers and caregivers on the disease and care of children can guide towards better health practices. Objective. Describe the perceptions and practices of mothers about the main health problems of their children during an emergency. Methodology. Quantitative-qualitative study, participatory action-research type with an intercultural perspective. Question guide was prepared for the exchange of knowledge with the focus group technique. Through inductive analysis of the transcripts, themes emerged. Results. Thirty-one mothers and caregivers attended the workshops. There were $48.6 \%$ emergencies due to diarrhea, fever and accidents. Home remedies, lack of hygiene in homes and lack of doctors on weekends were noted. Conclusions. Emergencies in children occured in almost half of the morbidity cases in the community studied. A new regionalization is necessary to reduce health gaps for children under five years of age.
\end{abstract}

\begin{abstract}
Resumen
Las percepciones y prácticas comunitarias hacia la enfermedad son influidas principalmente por la medicina tradicional. La perspectiva intercultural en salud, permite construir relaciones simétricas entre los saberes médico y tradicional. Uno de los grupos más vulnerables es el de menores de cinco años. Explorar las percepciones y prácticas de madres y cuidadoras sobre la enfermedad y atención de los niños, puede orientar hacia mejores prácticas de salud. Objetivo. Describir las percepciones y prácticas de las madres sobre los principales problemas de salud de sus hijos durante una emergencia. Metodología. Estudio cuanti-cualitativo, tipo investigación-acción participativa con perspectiva intercultural. Se elaboró guía de preguntas para intercambio de saberes con técnica de grupo focal. Mediante análisis inductivo de las transcripciones emergieron temáticas. Resultados. Asistieron a los talleres 31 madres y cuidadoras. Ocurrieron $48.6 \%$ emergencias por diarrea, fiebre y accidentes. Se percibieron remedios caseros, falta de higiene en los hogares y falta de médicos los fines de semana. Conclusiones. Las emergencias en los niños se presentaron casi en la mitad de los casos de morbilidad en la comunidad estudiada. Es necesaria una nueva regionalización para reducir brechas de salud de menores de cinco años.
\end{abstract}

Percepciones, Emergencia, Niños age in a Mayan community in Yucatán, México. ECORFAN Journal-Republic of Guatemala. 2020. 6-11:5-12.

$\dagger$ Researcher contributing first author. 


\section{Introduction}

Community perceptions and practices towards disease and access to health care are mainly influenced by traditional medicine, which in many regions of the world is the first contact of the population; In developing countries, it should be a link between rural communities and health services (Oliver, 2013). The strategy proposed by the World Health Organization on traditional medicine promotes its development and implementation in clinical practice in order to ensure access for all people to medical care (WHO, 2014-2023). However, in reality a scientific medicine is still perceived far from those practices and with little interest in knowing the cultural perceptions and practices towards the health-disease process, which increases the gap in access to health between communities and health services. The current physician follows a biomedical model of conventional medicine, which frequently underestimates the importance of social and cultural influence in the genesis of the disease; and that it does not favor the understanding between science and sociocultural knowledge.

In the last decade, perspectives aimed at strengthening a better understanding between the health services and the community population have been promoted in the field of health-disease, in response to the call of the indigenous population to respect their culture and rights (Salaverry, 2010). Through this perspective, communication and interaction between people and groups with specific cultural identities is possible, without the ideas and actions of one person or cultural group being above the other, favoring dialogue, agreement and, at all times, with this, integration and enriched coexistence between cultures (WHO, 2014-2023). The intercultural perspective in health aims to build symmetrical power relationships for interdisciplinary dialogue and between knowledge. It is precisely through the direct approach with the communities that experience health and disease from their cultural and ethnic vision, where it is possible to establish a dialogue to be able to communicate their knowledge and integrate it into scientific medical knowledge (Espinosa and Ysunza, 2009; Astaiza, Rodríguez, Guerrero and Portela, 2012).
In the communities, one of the most vulnerable groups that require study and that is part of the objectives of the new millennium is those under five years of age. According to WHO data, under-five mortality represents a fundamental indicator of the health and wellbeing of society. In 2016 it was reported that 5.6 million children died in the world before reaching the age of five, that is, 15,000 deaths of minors of that age group occurred per day. The greatest burden of mortality occurred in children in their first month of life, (approximately 44\%), due to preterm births, asphyxia during delivery and infections. Safe delivery and effective neonatal care are essential to prevent these deaths At the end of the neonatal period and up to five years of life, the leading causes of death are pneumonia, diarrhea, and malaria (WHO, 2018).

In Mexico, for the year 2019 it was estimated that the mortality rate in children under five years was $14.35 \times 1000$ live births (National Population Council, 2017); and the 5 main causes of mortality in children under one year were conditions originating in the perinatal period, respiratory distress of the newborn and other respiratory disorders, congenital malformations, influenza, pneumonia and accidents; and in the group aged 1 to 4 years, accidents, malignant tumors (mainly leukemias) and congenital malformations predominated (National Institute of Geography and Information Statistics, 2017).

During 2015 and 2016, 928 deaths of children under the age of five were reported in the State of Yucatán, with infant mortality rates of 13.6 and 13 per 1,000 live births, respectively. As antecedents of studies carried out in recent years in the State, perinatal conditions and congenital malformations were found as the first causes of death (Rodríguez, Marín, Andueza \& Ojeda, 2017). Other findings were the barriers in access to health services in emergency situations, which delayed timely treatment (Rodríguez, Hernández, Palmisano, Ojeda, Hoil and Andueza, 2019). 
In recent years, the concern to explore the perceptions and practices of mothers and caregivers when children fall ill has resurfaced; that provide guidance on barriers to access to care and allow proposing strategies aimed at preventing them. Some of them report the importance of promoting self-care with hygiene measures for the healthy growth of children (Usfar, Iswarawanti, Davelyna, Dillon, 2010; Chidziwisano, Slekiene, Mosler, Morse, 2020; Valencia, Thomson, Duncan and Andrew, 2016). However, in Mexico this type of study is scarce, especially in rural communities, where access to care is more difficult.

Similarly, there is little information on the specific morbidity of children at the local level and what are the practices that are being developed in the different health care settings at the community level, during the process of care in emergency cases. The foregoing will make it possible to contribute evidence that may be useful to the health system to undertake actions aimed at improving access to community health in this age group. The objective of the study is to describe the perceptions and practices of mothers about the main health problems of their children when an emergency occurs.

\section{Methods}

\section{Study site}

In Yucatán there are communities with a high degree of marginalization, as is the case of the Pustunich community, located in the municipality of Ticul, located in the south of the State of Yucatán, Mexico. Pustunich has a population of 2,480 inhabitants of which 203 $(8.2 \%)$ are under five years of age. $93.63 \%$ of the population is Mayan and $55.73 \%$ of the inhabitants speak the Mayan language, the fertility rate is 2.3 children per woman, $6.98 \%$ of the population is illiterate, with women almost double for each man; The level of schooling is 7.71 years completed (7.93 for men and 7.51 for women) (Pueblos de América.com, 2020). The community has an open population health center with first level care services; In case of requiring a specialized consultation or the care of an emergency, the patient has to be transferred to a clinic or hospital outside his locality. It also has a private practice, midwives and traditional doctors who participate in the care.

\section{Design and instrument}

A quantitative-qualitative study of the participatory action-research type with an intercultural perspective was designed. Initially, the health center records on morbidity of children under five years of age were reviewed. With these reports, the clinical causes of consultation and the main emergencies in children could be identified. Taking this information as a frame of reference, a question guide was prepared for discussions in participatory workshops with mothers and caregivers. The guide consisted of 6 questions: 1. What do children get sick or suffer from the most? 2. How do you know that something is happening to your child?; 3 . What are the warnings or signs that you see in the child that indicate that he is sick? 4 . What do you do when you realize that something is happening to your child?; 5 . What is the route that mothers take when they seek help for the care of their child?; and 6 . how is the child currently? The main purpose of the guide was the exchange of knowledge and knowledge about the perceptions and practices of mothers and caregivers about illnesses in children, their worldview in situations of illness that merited emergency care, as well as discussing experiences on the routes traveled to obtain access to medical care. The question guide was made in Spanish, these were validated by two medical specialists in social anthropology, who reviewed the content, construct, clarity and objective of the questions. This guide was applied to five moms prior to the workshops for clarity and understanding of the questions.

\section{Focus Groups for Discussion and recruitment}

Using a focus group discussion technique, participatory workshops were organized with mothers and caregivers of children under five years of age. The workshops were held from June to August 2019. The number and schedule of workshops were agreed with the participants and the recruitment was through an open invitation to the community through messages on social networks by the municipal commissioner, doctor of the center of the health center, the community kindergarten teacher and home visit to mothers of children under five years of age. 
For the recruitment, it was taken into account that they were mothers or caregivers of children under five years of age who were responsible for the child's health or that they shared decision-making in the child's care.

\section{Data collection}

To collect the qualitative information with the question guide, the main researcher acted as a facilitator in all the workshops, with 4 research assistants observing, writing the responses of the participants and managing the recording devices, as well as time management. In the first workshop with a focus group, the dynamics to develop during the workshops were explained, the participants were asked if they all understood and spoke Spanish and were asked to provide their name and age. Subsequently, an icebreaker dynamic was carried out, in order to build a relationship of trust between the researchers and the participants, and emphasis was placed on how important the opinion of each would be, and the participants were encouraged to speak freely. Similarly, to guarantee the confidentiality of the participants, their voluntary consent was requested to record the workshop discussions. All discussions were digitally recorded using a voice recorder and lasted approximately 45-60 minutes. The size of the groups was 7 to 8 participants. In total there were 4 groups and 8 discussion sessions. The transcription of the recordings was made immediately after each workshop.

\section{Data analysis}

The transcripts and notes of the focus group workshops were subjected to an inductive analysis, following a sequence of related steps: reading, coding, presentation, reduction and interpretation according to the themes and central ideas collected and observed (Ulin, Robinson, Tolley, 2006). Two conditions were considered for the construction of knowledge: the rescue of community knowledge about the social reality of diseases in children; and practices and experiences in seeking help for emergency care. From the reading and rereading of the texts, different themes emerged that included general categories that shared the themes that emerged. At each step of the process, we try to identify the thoughts, expressions and behaviors of the participants; and in this way, the information was reduced to the essential, to answer each question asked.
Each speech was characterized and interpreted individually, to finally be interrelated and presented through the network of concepts that gave answers to the original questions. All information was verified by a qualitative analysis specialist researcher.

\section{Ethical considerations}

Protocol number CIRB-2017-0007. The protocol was approved by the ethics committee of the Regional Research Center "Dr. Hideyo Noguchi". Each study participant was asked for their verbal informed consent to record the discussions during the same.

\section{Results}

During the two years studied, 132 consultations were granted, of which $40(30 \%)$ were for respiratory infections, $22(17 \%)$ for diarrheal disease, $22(17 \%)$ for dislocations and fractures and 48 (36\%) for various Causes; 74 (56.0\%) children needed to be referred to a second level hospital outside their locality; and of these, 36 $(48.6 \%)$ were referred to emergency.

The workshops were attended by 31 mothers and caregivers of children under five years of age. The age range of the participants was from 18 to 67 years, with a mean of $34.6 \pm$ 10.66. Regarding the number of children, they cared for, $25(80 \%)$ mentioned that they had one child under the age of five under their care and 6 (20\%) had 2.

During the dialogue in the workshops and in response to the question of what the children of Pustunich get sick or suffer more, themes and categories common to them emerged, which are listed in Table 1.

\begin{tabular}{|c|c|}
\hline Topics & Categories \\
\hline $\begin{array}{ll}\text { Acute } & \text { diarrheal } \\
\text { diseases } & \\
\end{array}$ & \multirow{3}{*}{$\begin{array}{l}\text { Emergency referrals } \\
\text { Risks that exist in the } \\
\text { community } \\
\text { Disease needs }\end{array}$} \\
\hline $\begin{array}{ll}\text { Acute } & \text { respiratory } \\
\text { infections } & \\
\end{array}$ & \\
\hline Accidents & \\
\hline $\begin{array}{l}\text { Access to health } \\
\text { services }\end{array}$ & Emergency care routes \\
\hline
\end{tabular}

Table 1 Emerging topics on the main diseases and conditions of children 
When asked if they had had to take their children to another clinic or hospital outside their locality for having presented an emergency (emergency referrals), 25 (80\%) reported having had it at least once with their children; and the most frequent were due to acute diarrheal diseases in $9(36.0 \%)$ children; and fever and accidents in 5 (20\%) children (Table 2).

\begin{tabular}{|l|l|l|}
\hline \multicolumn{1}{|c|}{ Emergency } & \multicolumn{1}{c|}{$\begin{array}{c}\text { Number of } \\
\text { participants }\end{array}$} & \multicolumn{2}{|c|}{$\begin{array}{c}\text { Causes of the } \\
\text { emergency }\end{array}$} \\
\hline $\begin{array}{l}\text { Acute } \\
\text { Diarrheal } \\
\text { Diseases }\end{array}$ & $9(36 \%)$ & $\begin{array}{l}\text { Diarrhea and } \\
\text { vomiting }\end{array}$ \\
\hline Fever & $5(20 \%)$ & $\begin{array}{l}\text { Increased body } \\
\text { temperature }\end{array}$ \\
\hline $\begin{array}{l}\text { Respiratory } \\
\text { diseases }\end{array}$ & $3(12 \%)$ & $\begin{array}{l}\text { Asthma, and } \\
\text { bronchiolitis, and } \\
\text { pneumonia }\end{array}$ \\
\hline Accidents & $5(20 \%)$ & $\begin{array}{l}\text { Fractures, head } \\
\text { injuries, and viper } \\
\text { bite }\end{array}$ \\
\hline Others & $3(12 \%)$ & $\begin{array}{l}\text { Seizures and } \\
\text { attempted suicide. }\end{array}$ \\
\hline $\mathrm{n}=25$ & \multicolumn{2}{|l}{} \\
\hline
\end{tabular}

Table 2 Main causes of emergencies in children reported by participants

Regarding the current health status of the children who had had to be treated in an emergency, the mothers mentioned that 24 (96\%) were healthy; and only one continued his treatment in a psychiatric hospital.

The discourse of mothers and caregivers about how they realize that something is happening to their child, they perceive that it depends on the child's illness or condition; In the case of getting sick with diarrhea, children present weakness, drowsiness, abdominal pain and they go to the toilet:

"The child stops playing, he looks tired, he is sleepy".

"Well, his belly hurts and he makes water when he goes to the bathroom, he does several times".

In the case of respiratory diseases, mothers and caregivers state that respiratory distress, which they call "acid", is a very common condition in children:

"... I was taking my 8-year-old granddaughter to the hospital and a neighbor asked me what the girl has and I told her that acid, she always has it for the month of May, it is dry season"
"Children suffer a lot from asthma, when she shows up she gives a lot of acid, she is suffocating because they feel like they are drowning and they can't stand it anymore"

When mothers and caregivers realize that something is happening to the child, the most experienced are the ones who usually make the decision that the child should be evaluated and according to their experience, they first resort to a remedy at home before taking them to the doctor. There is also the belief that illnesses can only be alleviated by a healer, through an abdominal massage called "sobada", to alleviate abdominal pain; if the pain persists, then take it to the doctor:

"First we give them a remedy for stomach pain and then if it does not improve we take it to the health center, the remedy is something fresh made up of mint, peppermint and pennyroyal plants and we give it to them to drink."

"The most important thing to do is give him serum; and when he has had diarrhea more than 3 times in an hour, he must be taken to the doctor.

The caregivers also mentioned that when they realize that children are sick with something respiratory, if they only have the flu, they usually give them a remedy. What alerts most caregivers that they have to go to an emergency service is when they see that the child cannot breathe,or begins to breathe very quickly. In the community, this type of breathing is called "acid":

“...... and he tells me: if you are not afraid, when the hail falls, let the girl come out to pick it up, whatever she wants to eat, let her eat it ... When the hail fell, my daughter told me: Mommy, If the neighbor says that this is the girl's medicine, let her go out to collect, and I say well, let her stay at the blessing of God, if it is your cure, at once, jump to collect (the hail). She got wet, her clothes got soaked and as she picks it up, she eats it. The lady told me that I have to pick up some and put the hail in a little bottle, that's what my granddaughter is going to drink. There she is! So, I did ..., From that my granddaughter was cured". 
... I go out to look for the mauve herb, but when I get rid of it, I just cut the pure root, I take out up to two bushes like that, I wash it well and put it to boil, like for a liter of water, and it remains reddish like rust; They drink it, without sugar or anything, it doesn't taste bad, just bitter, but it does feel weird when taking the first drink. But if I tell him that this is his medicine, he makes an effort and takes it and notice that it stopped harming him, because if not, he can't hold out like that, with rain on top, then the acid starts from the asthma he suffers, but that is his cure, the root of the mallow grass".

Caregivers perceive that children in the community get more ill due to lack of care and lack of housing; They know about the things that put children at risk of getting sick with diarrhea and in the discourse, concepts emerge about the lack of hygienic measures and the conditions in which the home is found:

"Sometimes children's hands are dirty with mud, because our houses have no soil and that makes them sick".

"Here in the town, they sell food on the street, if they don't have clean hands and eat it, they can get sick".

Another issue that emerged was accidents, which mothers and caregivers perceived to be something really worrisome and for which children die in the community. Despite the fact that other ailments such as diarrhea and respiratory problems are more common, when the phrase "risk of dying" was mentioned, caregivers perceive that they are very marked that "accidents are something important that must be prevented and addressed." They mentioned burns at home and asphyxia and trauma as the main accidents. When accidents occur, if it is a small injury, they can put a remedy, but if it is something more than that, they usually go directly to the emergency service, "the remedies in this case are practically ruled out and we seek immediate attention." They also mentioned that the majority of accidents are the fault of the mother's carelessness:
"... sometimes mothers who are careless burn children. There is a girl who was 6 years old, her mother had something on the fire and when she approached (the girl) to the candle, her clothes caught fire, she was hospitalized for about a month, her little arm and her chest burned; burns are frequent here".

"Let the babies lie down, turn around and suffocate, sometimes just playing children fall and hit their heads, sometimes we send them to buy, and they can run over them and the child can suddenly come out."

Regarding access to health services, the discussion focused on the routes to seek care, on which they mentioned that the shift for outpatient care in the health center is very limited and that doctors are needed to provide the service during the weekend; that is why they have to go to a private consultation or leave the community to seek the child's care:

"We take our son to the private, because in the health center there are never records".

"When (the child) does not look good with what they give him in the health center, I take him directly to the pediatrician".

"It happened to me that I went to the health center and since there was no one to take care of the child, I quickly returned home for the motorcycle and we went to Ticul, that took me a few minutes because I live close".

\section{Conclusions}

The perceptions of mothers and caregivers about the illnesses suffered by children under the age of five in the Pustunich community coincide with the main causes of consultation reported by the local health center. However, they perceive that accidents in children are much more frequent than they are reported, so the focus must be placed on preventing them and obtaining a better record. Home remedies are in the first instance the solution to many of the problems, without having to take the child to the health center; only if the remedy is ineffective is it evaluated by the doctor; These practices are also observed in other communities around the world where resources for emergency care are scarce (Dewan, Mummareddy, Wellons 3rd and Bonfield, 2016). 
From the discourse of mothers and caregivers we can see that they have a good knowledge of the signs and symptoms that correspond to the conditions and there are local practices that they trust and with which they have had good results. These same results are presented in other countries and are part of the cultural identity of the population (Bhalla, Gupta, Nanda, Mehra and Verma, 2019; Nitin et al, 2016).

Perceptions about children's health care reflect that there is still much to be done to improve the quality of access and timely care of emergencies. The lack of a doctor, resources and local equipment to treat the most basic emergencies puts the minor at high risk of suffering fatal consequences during their transfer to another clinic. In Yucatán, since the regionalization of health services in 1986 (Valencia, Marco, Olvera, Serrano and Márquez, 1986) there are no studies that provide evidence to propose the changes that are required to improve the quality of access and care for the health of minors. The new regionalization is a process that must be implemented in the short term, to reduce the gaps that prevail in rural communities and that put the health of children under five years of age at risk.

\section{References}

Oliver, S.J. The role of traditional medicine practice in primary health care within Aboriginal Australia: a review of the literature. J Ethnobiology Ethnomedicine 9, 46 (2013). https://doi.org/10.1186/1746-4269-9-46

OMS. Estrategia de la OMS sobre medicina tradicional 2014-2023 (2013). Disponible en: https://apps.who.int/medicinedocs/documents/s 21201es/s21201es.pdf

Salaverry, O. Interculturality in health. Rev Peru Med Exp Salud Publica. 2010 Mar;27(1):80-93. DOI: $10.1590 / \mathrm{s} 1726-46342010000100013$ https://www.ncbi.nlm.nih.gov/pubmed/2107245 4

Espinosa, L., Ysunza, A. (2009). Diálogo de saberes médicos y tradicionales en el contexto de la interculturalidad en salud Ciencia Ergo Sum, vol. 16, núm. 3, pp. 293-301. Available in: http://www.redalyc.org/articulo.oa?id=1041205 7010
Bravo, A., Nohra, X., Rodríguez, S., Guerrero, N., Portela, H. (2012). Diálogo intercultural en salud: una estrategia para rescatar los saberes y prácticas médicas en torno a la salud materno infantil de las comunidades afrocaucanas. Revista Virtual Universidad Católica del Norte, núm. 37, pp. 180-211. Available in: http://www.redalyc.org/articulo.oa?id=1942245 68010

OMS. Reducción de la Mortalidad en la Niñez. (2018). Accessed August 27, 2019 available at: http://www.who.int/es/news-room/factsheets/detail/children-reducing-mortality

CONAPO. (2017). Indicadores demográficos de Yucatán en el año 2017. Available at: http://www.conapo.gob.mx/work/models/CON APO/Mapa_Ind_Dem18/index.html

INEGI. (2018). Características de las defunciones registradas en México durante 2017. Retrieved August 27, 2019 from: https://www.inegi.org.mx/contenidos/saladepre nsa/boletines/2018/EstSociodemo/DEFUNCIO NES2017.pdf

INEGI. (2017). Principales causas de mortalidad por residencia habitual, grupos de edad y sexo del fallecido. Accessed August 27, 2019 available at: https://www.inegi.org.mx/sistemas/olap/registro $\mathrm{s} /$ vitales/mortalidad/tabulados/ConsultaMortali dad.asp

Rodríguez, E., Martín, A., Andueza, M., Ojeda, R. (2017). Major causes of death in children under five years by sanitary jurisdiction. Yucatán 2010-2014. Journal Law and Economy; 1(1):1927.

Rodríguez, E., Hernández, B., Palmisano, E., Ojeda, R., Hoil, J., Andueza, G. (2019). Defunciones en menores de cinco años por área geográfica en Yucatán, Méx. Visum Mundi, Vol. 3, No. 1, online AcademiaJournals.com

Usfar, A., Iswarawanti, D., Davelyna, D., Dillon, D. (2010) Food and personal hygiene perceptions and practices among caregivers whose children have diarrhea: a qualitative study of urban mothers in Tangerang, Indonesia. J Nutr Educ Behav. Jan-Feb 2010;42(1):33-40. doi: 10.1016/j.jneb.2009.03.003. 
Chidziwisano, K., Slekiene, J., Mosler, H.J., Morse, T. (2020). Improving Complementary Food Hygiene Behaviors Using the Risk, Attitude, Norms, Ability, and Self-Regulation Approach in Rural Malawi. Am J Trop Med Hyg. ;102(5):1104-1115. doi: 10.4269/ajtmh.190528 .

Valencia, A., Thomson, C., Duncan, B., Andrew, A. (2016). Evaluating Latino WIC Mothers' Perceptions of Infant's Healthy Growth: A Formative Assessment. Matern Child Health J. 20(3):525-33. doi: 10.1007/s10995-015-1850-7.

Pueblos de América.com. Pustunich, Ticul, 2020 https://mexico.pueblosamerica.com/i/pustunich2/

Ulin, P., Robinson, E., Tolley, E. (2006). Investigación aplicada en salud pública. Métodos cualitativos. Organización Panamericana de la Salud. Publicación científica y técnica 614. Washington, D.C. 286 p.

Dewan, M., Mummareddy, N., Wellons, J., Bonfield, Ch. (2016). Epidemiology of Global Pediatric Traumatic Brain Injury: Qualitative Review. World Neurosurg;91:497-509.e1. doi: 10.1016/j.wneu.2016.03.045. Epub 2016 Mar 25

Bhalla, K., Gupta, A., Nanda, S., Mehra, S., Verma, S. (2019). Parental knowledge and common practices regarding acute respiratory infections in children admitted in a hospital in rural setting. J Family Med Prim Care;8(9):2908-2911. doi: 10.4103/jfmpc.jfmpc_510_19. eCollection 2019 Sep.)

Nitin, J., Punya, S., Hariharan, B., Dhanush, K., Fathima, R., Mohamed, J., Nita, J., Shashidhar, M., Sharada, Rai. (2016). Prevalence, risk factors and treatment practices in diarrhoeal diseases in south India. Environ Health Prev Med. ;21(4):248-57. doi: 10.1007/s12199-0160521-7. Epub 2016 Mar 4.)

Valencia, G., MARCO, J., OLVERA, J., SERRANO, O., MÁRQUEZ, A. (1986). Regionalización de México basada en indicadores de atención primaria a la salud propuestos por la OMS. https://saludpublica.mx/index.php/spm/article/v iew/5354/5573). 